\title{
Urban land planning: The role of a Master Plan in influencing local temperatures
}

\author{
Cláudia V. Viegas ${ }^{\mathrm{a}, *}$, Dejanira Luderitz Saldanha ${ }^{\mathrm{b}}$, Alan Bond ${ }^{\mathrm{c}, \mathrm{d}}$, José Luis Duarte Ribeiro ${ }^{\mathrm{e}}$, Paulo M. Selig ${ }^{\mathrm{a}}$

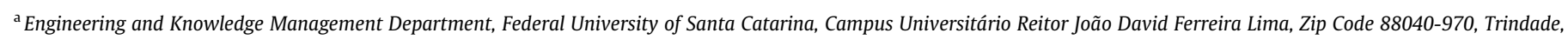 \\ Florianópolis, Santa Catarina, Brazil

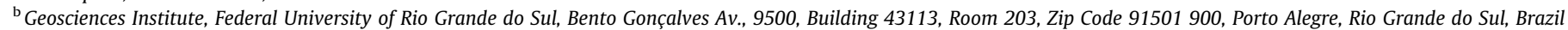 \\ ${ }^{\mathrm{c}}$ School of Environmental Sciences, University of East Anglia, Norwich NR4 7TJ, UK \\ ${ }^{\mathrm{d}}$ School of Geo and Spatial Sciences, North-West University, Potchefstroom Campus, Private Bag X6001, Potchefstroom 2520, South Africa

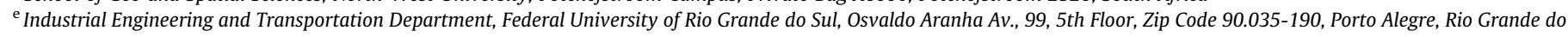 \\ Sul, Brazil
}

\section{A R T I C L E I N F O}

\section{Article history:}

Received 9 July 2012

Received in revised form 21 May 2013

Accepted 26 May 2013

Available online 9 August 2013

\section{Keywords:}

Urban land planning

Local climate change

Temperature increase

Master Plan

\begin{abstract}
A B S T R A C T
Land use planning (LUP) is central for managing issues related to climatic variation in urban environments. However, Master Plans (MPs) usually do not include climatic aspects, and few studies have addressed climate change at the urban scale, especially in developing countries. This paper proposes a framework with ten categories for assessment of climatic variation in urban LUP. Each category comprises attributes that describe a complex of relationships in influencing local temperature variations. They are analyzed for the case of the Master Plan of Porto Alegre (MPPA), the Southernmost metropolis of Brazil. It is concluded that the MPPA is strongly grounded in climate-related land and zoning coordination, but exhibits weaknesses in building, cartographical and social aspects considered synergistically relevant for tackling problems related to urban climate variation. Furthermore, the MPPA does not contain provisions related to monitoring of local climate and greenhouse gases (GHG) emissions and it is ineffective for improving energy efficiency. Specific MPPA failures stemming from these weaknesses include: an increase of $21.79 \%$ in the city's urbanized area from 1986 to 2011 to accommodate a similar increase in population, with significant horizontal sprawl; average temperature rise of $0.392{ }^{\circ} \mathrm{C}$ from 1991-2000 to 2001-2010, with statistically significant increases in temperature found since 1931; significant vehicle traffic increases, especially since 2007. From these findings, it is possible to conclude that the MPPA does not offer answers to all the imbalances related to land use, and therefore gives insufficient support to tackle the issue of rising temperatures.
\end{abstract}

(c) 2013 Elsevier Ltd. All rights reserved.

\section{Introduction}

Climate change at the local scale is a recently studied phenomenon around which several uncertainties remain based on: the lack of scientific agreement that it can be demonstrated to occur at the urban scale (Schiermeier, 2010; Jankovic \& Hebbert, 2012); the absence of sufficient research on climate change at this scale (Blakely, 2007; Blanco et al., 2009; Hunt \& Watkiss, 2011); and the presence of uncertainty on how to assess it (Alcoforado, Andrade, Lopes, \& Vasconcelos, 2009; Bentley, 2007; Fernau, Makofske, \& South, 1993). Furthermore, the sparse nature and large variability of available data (van de Voet et al., 2012), associated with the complexity of the natural and built environments of each municipality (Aydin

\footnotetext{
* Corresponding author. Tel./fax: +55 214837212451.

E-mail addresses: claudiav@egc.ufsc.br (C.V.Viegas), dejanira.saldanha@ufrgs.br (D.L. Saldanha), alan.bond@uea.ac.uk (A. Bond), ribeiro@producao.ufrgs.br (J.L.D. Ribeiro), selig@egc.ufsc.br (P.M. Selig).
}

\& Çukur, 2012; Grimm et al., 2008) make it difficult to outline a credible set of attributes for determining the state of local climate change. "Cities interact with the atmosphere over a wide range of scales from the large-scale processes, which have a direct impact on global climate change, to smaller scales, ranging from the conurbation itself to individual buildings" (Hidalgo, Masson, Baklanov, Pigeon, \& Gimeno, 2008: 354). According to Aydin and Çukur (2012), a local model for climate change is difficult, if not impossible, to develop because the energy use for households is affected by the characteristics of the local climate; the vegetation of each region varies, as does the carbon absorption capacity; and each urban settlement has different development types and density.

Land Use Planning (LUP) involves a complex interdisciplinary set of approaches (Shoshany \& Goldshleger, 2002; Yang et al., 2008) with clear implications for urban climate behavior. It can be considered the umbrella under which it is possible to identify, classify and assess or measure several variables, and describe how they relate reciprocally in order to better understand the local 
climatic variation. Issues embraced by LUP can be related to climate variation (Wegener, 2001), and LUP is potentially the key for local climate change assessment (Cantarello, Newton, \& Hill, 2011).

However, "[a]lthough the characteristics of the urban climate have been known for a long time, there has been very little application of climate knowledge in urban planning" (Alcoforado et al., 2009: 56). "Review of literature and precedents in three relevant fields (integrated assessment of climate change, conventional urban planning, and applications of visual media) suggests, in particular, that there are few if any approaches or frameworks for 'connecting the dots' between global climate science and information on the one hand, and the range of local community activities and options on the other" (Sheppard et al., 2011: 401). One such approach is depicted by Solecki and Oliveri (2004). They argue that in recent decades, the science of global change has begun to appreciate the importance of land use/cover measures, so climate change scenarios can be downscaled through LUP models.

At the municipality level, Master Plans (MPs) are the tool which facilitates the connection between LUP and local climate change. They serve as the guideline for land use decisions (Cabanillas, Aliseda, Gallego, \& Jeong, 2013), and can influence the microclimate in the long term (Benzerzour, Masson, Groleau, \& Lemonsu, 2011). Nevertheless, according to Alcoforado et al. (2009), climate maps are very rarely embedded in MP and. if they are, the scale is inappropriate. A common failure of MP is embracing a large number of indicators that are difficult to track and monitor (Mascarenhas, Ramos, \& Nunes, 2012; Saizen, Mizuno, \& Kobayashi, 2006), or presenting poor connections or lack of connections between indicators (Mascarenhas et al., 2012).

This paper discusses the role and effectiveness of a MP for understanding and controlling significant temperature increases in the urban environment over several decades. It proposes a framework of LUP categories whose aspects are compared with the provisions of the MP of Porto Alegre - the Southernmost metropolis of Brazil, taken as case study. The second section presents the methodological approach. The third section presents the results in two subsections: a debate on the difficulties of developing an urban climate change model as compared to global and regional studies, and a framework for assessment of climate change within LUP. In the fourth section, we present and discuss the case study of MPPA, and compare the main characteristics of the city's MP with the proposed LUP framework. The fifth section is dedicated to the final remarks and conclusions.

\section{Methodological approach}

For the purpose of understanding how climate change is recognized at the urban level, a broad literature review on climate change, from global to regional and local scales, was carried out. This included peer-reviewed studies on urbanization and rising temperatures. A second, narrower, review of peer-reviewed literature was performed through the advanced search facility of Science Direct with the expressions "models for climate change in cities" and "land planning, land use, land change" and "master plan", using the Boolean operator "AND". A total of 2764 documents were identified. The first 500 were examined for evidence of the existence of LUP content related to climatic variation in urban studies. A total of 39 articles, published between 2001 and 2013, were selected to build a framework in which the main attributes for LUP were assigned. This framework is represented in Table 1. Then, a case study approach, which "investigates a contemporary phenomenon in depth and within its real-life context" (Yin, 2009: 18), was adopted taking Porto Alegre city as the subject for which correspondence with the framework was tested. Effectiveness is here defined as the correspondence of the MPPA with the LUP framework. For the case study analysis, some technical procedures were performed including: the georeferencing and treatment of Landsat images using Envi software, and the counting of urbanized areas using AutoCAD; and the analysis of variance (ANOVA) of the historical series of average temperatures officially registered in Porto Alegre from 1931 to 2010 with a 0.05 significance level. This analysis was performed for periods of 30 years and 10 years respectively. This is consistent with the World Meteorological Organization (WMO) recommendation, which considers a 30 -years range to be a robust period for meteorological variation. A 10-year range can be also suitable for assessment because climate is a natural-human construct whose variation is recognized over a decade (Hulme, Dessai, Lorenzoni, \& Nelson, 2009).

\section{Results}

Urban areas cover just 3\% of the Earth's land surface, but their environmental impact is tremendous (Dewan \& Yamaguchi, 2009). In 2008 the proportion of the global population living in urban areas went above $50 \%$ for the first time, and by 2030 it is predicted to reach 60\% (Harlan \& Ruddell, 2011). According to Jusuf, Wong, Hagen, Anggoro, and Hong (2007: 232), “[t]he urban air temperature is gradually rising in all cities in the world". Urban heating has several synergistic causes, including the increase of carbon dioxide and GHG emissions (Kamal-Chaoui \& Robert, 2009; McCarthy, Best, \& Betts, 2010), land misuse due to lack of urban and traffic planning, excessive demographic concentration (McDonald et al., 2001; De Nazelle et al., 2011; Harlan \& Ruddell, 2011), intensive use of individual vehicles, and increasing building density with dramatic suppression of green areas (Dodman, 2009; Grimm et al., 2008; Gu, Hua, Zhang, Wang, \& Guo, 2011; Lankao, 2008; Parker, 2010; Patz, Campbell-Lendrum, Gibbs, \& Woodruff, 2008; Satterthwaite, 2007; Seto, Sánchez-Rodríguez, \& Fragkias, 2010; Solecki et al., 2004; Stephenson, Newman, \& Mayhew, 2010). In the following subsections we present the challenge of considering climate change of urban environments with some examples of cities that underwent significant climatic variation , and a set of attributes for LUP whose interactions are associated with local climactic variation.

\section{Downscaling climate change to urban environments}

Climate change is an undeniable reality (Adger, Arnell, \& Tompkins, 2005), and cities are the most geographically tangible scale at which wicked and routine problems occur (Batty, 2012), including climatic variation. The main difficulty that surrounds the relationship between local and global climate change is the lack of consistent studies to reliably draw links between both phenomena (Blakely, 2007; Fernau et al., 1993). Thus doubts exist on how to assess local level climate change (Bentley, 2007).

Schiermeier (2010: 284) states that climate change can only be studied through meteorological models with a resolution of about $1-3^{\circ}$ in latitude and longitude, and lower scales deliver coarse results. However, regional and local models are being developed and shed new light on the climatic small scale deadlock (Blanco et al., 2009; Houet \& Pigeon, 2011; Marengo et al., 2011; Sears, Raskin, \& Angilletta, 2011; Cooney, 2012; Grosling, McGregor, \& Lowe, 2012).

The debate on global and local models of climate change is far from resolution. Nevertheless, several studies can be identified to illustrate the reality of local temperature variation associated mainly with the lack of LUP. Temperature variation in cities is usually studied through the Urban Heat Island (UHI) approach, firstly employed by Luke Howard's experiments in the 19th century 
Table 1

Categories of LUP and associate variables.

\begin{tabular}{|c|c|}
\hline $\begin{array}{l}\text { Main label } \\
\text { Categories }\end{array}$ & LUP \\
\hline Urban sprawl/density(Ux) & 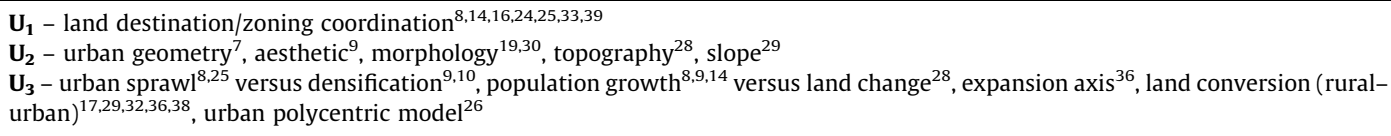 \\
\hline Building (Bx) & $\begin{array}{l}\mathbf{B}_{\mathbf{1}} \text { - building patterns }{ }^{2} \text {, building techniques, materials, structure, investments, size, geometry, density, height }{ }^{3,8,10,18,26,37,39}, \text { building } \\
\text { ratio/use }{ }^{25} \text {, space between buildings }{ }^{39} \\
\mathbf{B}_{\mathbf{2}}-\text { green roofs }^{13,30} \text {, green building }\end{array}$ \\
\hline Transport/traffic/mobility (Tx) & $\begin{array}{l}\mathbf{T}_{\mathbf{1}} \text { - transport planning }{ }^{1,29,33,34,35} \text {, traffic design }{ }^{9} \text {, transport networks }{ }^{18} \text {, transport versus/integrated with land use, TOD, planning } \\
\text { park spaces }{ }^{29,31,32} \text {, street width ratio } \\
\mathbf{T}_{\mathbf{2}} \text { - } \text { traffic mobility }^{4} \text {, accessibility }{ }^{16} \text { bicycle/pedestrian infrastructure }{ }^{11,21} \text {, sidewalk coverage }{ }^{8} \text {, walkable environment }{ }^{16}\end{array}$ \\
\hline Green spaces (Gx) & $\begin{array}{l}\mathbf{G}_{\mathbf{1}} \text { - open spaces, vegetation coverage }{ }^{1,25} \text {, green space provision }{ }^{8,13,15,16} \text {, urban trees management }{ }^{30} \text {, green cover ratio }{ }^{39} \text { versus } \\
\text { impervious surface ratio }{ }^{10,25,39} \\
\mathbf{G}_{\mathbf{2}} \text { - biodiversity and forests }{ }^{5} \text {, deforestation }{ }^{38} \text {, forest planning } \\
\mathbf{G}_{\mathbf{3}} \text { - farming areas }{ }^{27}\end{array}$ \\
\hline Energy (Ex) & $\mathbf{E}_{\mathbf{1}}$ - energy consumption ${ }^{1,32}$, energetic efficiency ${ }^{9,30,31}$, renewable energies ${ }^{5,13}$, energy system models ${ }^{33,34}$ \\
\hline Biophysical aspects (BAx) & $\begin{array}{l}\mathbf{B A}_{\mathbf{1}} \text { - air dispersion models, air pollution }{ }^{38} \\
\mathbf{B A}_{\mathbf{2}} \text { - rivers management }{ }^{1} \text {, rainfall models, floods avoiding }{ }^{13} \text {, groundwater models, sewer system }{ }^{3} \text {, waste/water management }{ }^{13} \\
\mathbf{B A}_{\mathbf{3}} \text { - monitoring of natural areas }{ }^{20} \text {, biological ecosystem } \text { models }^{33} \text {, soil resources }\end{array}$ \\
\hline $\begin{array}{l}\text { Local climate/temperatures } \\
\quad \text { variation }(\mathbf{C x})\end{array}$ & $\begin{array}{l}\mathbf{C}_{\mathbf{1}} \text { - } \text { climate stress }^{3} \\
\mathbf{C}_{\mathbf{2}} \text { - } \text { climate }^{7} \mathrm{zones}^{7}, \text { temperature measurement in different zones of the city } \\
\mathbf{C}_{\mathbf{3}} \text { - regional climate factors }{ }^{19}\end{array}$ \\
\hline GHG emissions (GHx) & $\mathbf{G H}_{\mathbf{1}}$ - GHG emissions per capita ${ }^{1}, \mathrm{CO}_{2}$ emissions $^{34}$, methane emissions (landfill) ${ }^{21}$ \\
\hline Cartographic data (CDx) & $\begin{array}{l}\mathbf{C D}_{1} \text { - cartographical representation of land, geographic data, land use maps }{ }^{6} \\
\mathbf{C D}_{2} \text { - climate maps }{ }^{2} \\
\mathbf{C D}_{3} \text { - satellite data }{ }^{17}\end{array}$ \\
\hline Social aspects (Sx) & $\begin{array}{l}\mathbf{S}_{\mathbf{1}} \text { - } \text { safety }^{9} \text {, quality of life }{ }^{4}, \text { social welfare }{ }^{23}, \text { environmental quality }^{37} \\
\mathbf{S}_{\mathbf{2}} \text { - social behavior towards environment }{ }^{21,33}\end{array}$ \\
\hline
\end{tabular}

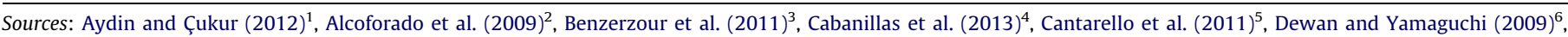

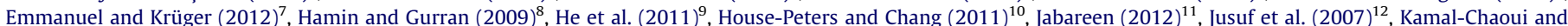

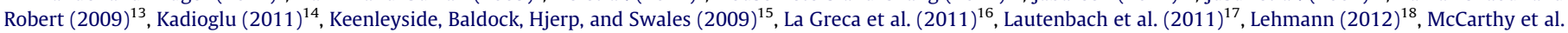

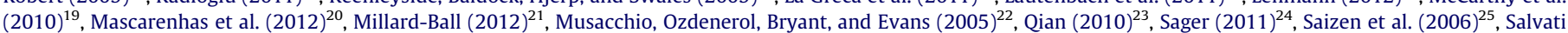

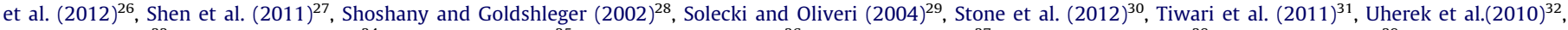
Wegener $(2001)^{33}$, Wende et al. $(2012)^{34}$,Willoughby $(2012)^{35}$, Wu and Zhang $(2012)^{36}$, Yang et al. $(2008)^{37}$, Yoon and Lee $(2003)^{38}$, Zhao et al. $(2011)^{39}$.

(Hidalgo et al., 2008; Jankovic \& Hebbert, 2012). UHI refers to temperatures that are often higher in the city centre in comparison with the outskirts of the city (Hallegatte \& Henriet, 2011). The main recognized causes of UHI are vegetation suppression with subsequent coverage by impervious surfaces (concrete or asphalt); tall buildings, with structures close to each other and consequent changes in radiation fluxes; and heat released by human activity (Frumkin, Hess, \& Stone, 2010; Huang, Zhou, \& Cadenasso, 2011; Solecki et al., 2004). The temperature differences can reach up to $10{ }^{\circ} \mathrm{C}$ for large urban agglomerations.

We recovered the following examples of research about cities' temperature variations associated with land use change, covering a diverse range of time (from a decade to almost 60 years) and with annual average temperatures increasing from less than $0.5^{\circ} \mathrm{C}$ to more than $1{ }^{\circ} \mathrm{C}$ : Fernau et al. (1993) for several US municipalities; Karaca, Tayanç, and Toros (1995) for Istanbul and Ankara, in Turkey; Tayanç and Toros (1997) for four large cities in Turkey; Eliasson and Svensson (2003) for Göteborg, Sweden; Solecki et al. (2004) for New Jersey, USA; Song, Cannon, and Whitfield (2007) for 720 meteorological stations in China; Hu and Jia (2010) for Guangzhou, China; Elagib and Abdu (2010) for 36 islands of the Arabian Gulf; Moser, Norton, Stein and Georgieva. (2010) for Mombasa, Kenya; Tokairin, Sofyanb, and Kitada (2010) for Jakarta, Indonesia; Gu et al. (2011) for the region of the Yangtze River Delta, China; Fischer, Gemmer, Lüliu, and Buda (2011) for Zhujiang River Basin, China; Kim and Kim (2011) for several municipalities of South Korea; and Emmanuel and Krüger (2012) for 561 Japanese meteorological stations located in cities.
These examples bring evidence of the close relationships between land use change (controlled by LUP where it is in place) and local temperature variations. Therefore it is possible to assume that LUP aspects are strongly linked to local climate change behaviors, and the deployment of a LUP framework is assumed to be useful for a grounded study of local temperature variations.

\section{LUP framework and the role of the Master Plan in local climatic variation}

LUP is a spatial management instrument (Wende, Bond, Bobylev, \& Stratmann, 2012) aimed at promoting social welfare (Qian, 2010), and can be considered the umbrella below which it is possible to identify, classify and assess or measure several aspects of city dynamics related to local climatic variation. LUP relates to zoning, density and height of buildings, and proportion of underdeveloped land in each property (Kamal-Chaoui \& Robert, 2009; Sager, 2011; Saizen et al., 2006), and to models of economic and regional development which include "land and housing market models, plant and facility location models, spatial diffusion models, migration models, travel and goods transport models and urban land-use models" (Wegener, 2001: 224). It is associated with spatial development (Yang et al., 2008), and it is therefore interdisciplinary because it involves ecological, economic and social aspects and their associated subtopics (Wegener, 2001), besides urban density (Aydin \& Çukur, 2012; House-Peters \& Chang, 2011; Jabareen, 2012), compact form (Lehmann, 2012) and topographical, climatic and geological features (Kadioglu, 2011; Zhao, Fu, Liu, \& Fu, 2011). 
LUP also influences population distribution, safety, aesthetics, infrastructure, and transport (He et al., 2011).

(Researchers have linked patterns of land use with public transport policies (Tiwari, Cervero, \& Schipper, 2011; Uherek et al., 2010; Willoughby, 2012) and climatic change at the local scale (Solecki \& Oliveri, 2004). Based on a literature review on LUP (including land use and changes over time), it is possible to highlight the main aspects that influence climatic variation (Table 1). These are described in the next subsection 'Urban sprawl/density' to 'Social aspects', and applied to the case of Porto Alegre city through comparison with the provisions and effectiveness of the city's MP in last section.

\section{Urban sprawl/density}

There are controversial studies about the relationship between urbanization and long term temperature modification. Mostly (for example, Gu et al., 2011; Parker, 2010; Seto et al., 2010; Stephenson et al., 2010; Dodman, 2009; Grimm et al., 2008; Lankao, 2008; Patz et al., 2008; Satterthwaite, 2007; Solecki et al., 2004; McDonald et al., 2001) they advocate that demographic concentration, if well managed, entails reduction of energy consumption for transportation and domestic uses (Castello, 2011; Dodman, 2009; Roy, 2009). However, there are claims about the need to include behavior issues and lifestyles while looking at the trade-offs between economies and diseconomies of agglomerations (Batty, 2012; Heinonen, Kyrö, \& Junila, 2011).

The main aspects to be considered for urban sprawl/density are: land zoning coordination - ability to plan urban spaces in order to improve energy use and transport efficiency (Saizen et al., 2006; Wegener, 2001; Hamin \& Gurran, 2009; Salvati, Munafo, Morelli, \& Sabbi, 2012; Kadioglu, 2011; La Greca, Barbarossa, Ignaccolo, Inturri, \& Martinico, 2011; Sager, 2011; Zhao et al., 2011); urban geometry and morphology, related to the natural shape of the city (Shoshany \& Goldshleger, 2002;Solecki \& Oliveri, 2004; McCarthy et al., 2010; Emmanuel \& Krüger, 2012; He et al., 2011; Stone, Vargo, \& Habeeb, 2012); land sprawl based on densification (Hamin \& Gurran, 2009; He et al., 2011; House-Peters \& Chang, 2011; Saizen et al., 2006); population growth (Hamin \& Gurran, 2009; He et al., 2011; Kadioglu, 2011); land use change or land conversion (Shoshany \& Goldshleger, 2002; Yoon \& Lee, 2003; Solecki \& Oliveri, 2004; Lautenbach, Kugel, Lausch, \& Seppelt, 2011; Uherek et al., 2010; Wu \& Zhang, 2012).

\section{Building}

Many studies associate building and temperature increases in cities with zoning (Saizen et al., 2006) or arrangements among different construction structures such as, for instance, villas and modern apartment towers, interacting with air conditions to create a variety of urban climates (Alcoforado et al., 2009). Others refer to density distribution of buildings (Kamal-Chaoui \& Robert, 2009; Salvati, Munafo, Morelli, \& Sabbi, 2012), different building heights, street width, construction techniques and materials (Benzerzour et al., 2011; Hamin \& Gurran, 2009; House-Peters \& Chang, 2011; Salvati et al., 2012; Yang et al., 2008; Zhao et al., 2011) as setting the conditions for temperature variations in cities. Lehmann (2012) mentions the use of less raw material and material which offers better thermal condition for avoiding the need for space heating. The ratio between built and green spaces (Zhao et al., 2011), use of green building techniques (Millard-Ball, 2012) and green roofs and pavements (Stone et al., 2012) are also relevant for decreasing the need for heating.

\section{Transport/traffic/mobility}

Two set of core aspects are identified. The first is transport planning (Wegener, 2001; Solecki \& Oliveri, 2004;Aydin \& Çukur, 2012; Wende et al., 2012; Willoughby, 2012), including traffic design (He et al., 2011); transport networks (Lehmann, 2012); Transport Oriented Development (TOD), which regarded as a mixed-use community in which several types of activities including commercial, residential and services are within $610 \mathrm{~m}$ walking distance of a transit stop (Solecki \& Oliveri, 2004; Tiwari et al., 2011; Uherek et al., 2010); and street width ratio (Benzerzour et al., 2011; Zhao et al., 2011). The second is traffic mobility (Cabanillas et al., 2013) comprising accessibility (La Greca et al., 2011); bicycle/pedestrian needs (Jabareen, 2012; Millard-Ball, 2012); and sidewalk coverage (Aydin \& Çukur, 2012; Saizen et al., 2006; Salvati et al., 2012). In all cases the main proposal is to integrate mobility with rational land use.

\section{Green spaces}

LUP for green spaces can be categorized into three main groups of aspects: (i) vegetation coverage (Aydin \& Çukur, 2012; Saizen et al., 2006) including public provision for green areas (Hamin \& Gurran, 2009; Kamal-Chaoui \& Robeert, 2009; Keenleyside et al., 2009; La Greca et al., 2011), urban trees management (Stone et al., 2012), and green cover ratio (Zhao et al., 2011) versus impervious surface ratio (House-Peters \& Chang, 2011; Saizen et al., 2006; Zhao et al., 2011); (ii) biodiversity, encompassing forests (Cantarello et al., 2011), deforestation (Yoon \& Lee, 2003), and forest planning (Wende et al., 2012); and (iii) farming areas (Shen, Ochoa, Shah, \& Zhang, 2011).

\section{Energy}

The main references in the literature associating energy and LUP are about consumption rates (Aydin \& Çukur, 2012; Uherek et al., 2010), efficiency improvement (He et al., 2011; Tiwari et al., 2011; Wegener, 2001) and renewable energy use (Cantarello et al., 2011; Kamal-Chaoui \& Robert, 2009; Wegener, 2001; Wende et al., 2012).

\section{Biophysical aspects}

Biophysical aspects embrace all aspects of air, water and land, such as (i) air pollution and air dispersion models (Yoon \& Lee, 2003); (ii) hydrological management including management of rivers (Aydin \& Çukur, 2012), rainfall models, flood avoidance, wastewater management (Kamal-Chaoui \& Robert, 2009), groundwater models and sewer systems (Benzerzour et al., 2011); and (iii) monitoring of natural areas (Mascarenhas et al., 2012), biological ecosystem models (Stone et al., 2012) and soil resources (Yang et al., 2008). The main target is to coordinate the natural elements with regard to ecosystem services.

\section{Climate}

Three main aspects were identified as relevant for local climate associated with LUP: (i) climate stress (Benzerzour et al., 2011), associated with extreme climatic events; (ii) temperatures measured in different zones of the city (Jusuf et al., 2007); and (iii) regional climate factors (McCarthy et al., 2010).

\section{GHG emissions}

The common approach related to general GHG emissions or GHG emissions per capita is how to include this aspect effectively in LUP (Aydin \& Çukur, 2012; Wende et al., 2012), because there are behavioral issues implied in emissions that cannot simply be controlled by planning (Millard-Ball, 2012).

\section{Cartographical data}

Land maps (Dewan \& Yamaguchi, 2009), climate maps (Alcoforado et al., 2009) and satellite data (Shen et al., 2011) are regarded as the main cartographical representations in LUP. However, "Master Plans hardly ever included any climate maps and, 
whenever they did, their scale was inappropriate for direct application" (Alcoforado et al., 2009: 57).

\section{Social aspects}

The main social aspects mentioned in the literature in relation to LUP are safety (He et al., 2011), quality of life (Cabanillas et al., 2013), social welfare (Qian, 2010), environmental quality (Yang et al., 2008), and behavior towards the environment (Millard-Ball, 2012; Wegener, 2001).

\section{The case of Porto Alegre LUP: main provisions and effectiveness of the MP}

The Southernmost Brazilian metropolis, Porto Alegre is the capital of Rio Grande do Sul, located in the Central Depression of the State. It has as geographical coordinates $30^{\circ} 02^{\prime} 0^{\prime \prime}$ South and $51^{\circ} 12^{\prime} 00^{\prime \prime}$ West (Fig. 1). The city was firstly established in 1772 , occupies $497 \mathrm{~km}^{2}$, and has a population of 1.4 million inhabitants (FEE-RS, 2011), with a density of 2836 persons $/ \mathrm{km}^{2}$. It presents a heterogeneous relief, with mountains and hills to the East and South, plains in the central and Northern areas, and low land and coastal area to the West (Dias, 2011).

Experiencing a subtropical climate, Porto Alegre is influenced by both maritime tropical and continental systems (Rossatto, 2011). Hasenack (2008) classifies the vegetation of Porto Alegre as native forest, degraded forest, shrubs, grasslands, planted, and managed fields. The majority of the city's vegetation was replaced by anthropogenic occupation during the urbanization process, but $24.1 \%$ of the original vegetation remains - of this amount, $13.9 \%$ is forest cover and $10.2 \%$ is underbrush. The city has sprawled from the centre in a radial shape. The South of the city keeps the most expressive original landscapes strips, and even with recent occupation, it presents low impermeability rates in comparison with the central and near-central neighborhoods, where the soil is almost all paved. Around the hills, to the East side of the city, there is a high concentration of irregular occupation, and flood episodes are frequent.

Data from the Urban Municipal Planning Office of Porto Alegre City Hall (SPM, 2011) reveal that the city became the first capital in Brazil to have a Master Plan - in 1914. Until 1938, MPPA was fo- cused on transportation and road conditions, but it started to change in 1959, when a new plan covered housing, work, leisure and circulation (transport) issues. The more recent version of the MPPA was launched in 1999 and underwent legal amendments in 2010 and 2011. The main statements of the MPPA are described in Table 2.

Liberman and Saffer (2011) highlight the following features of the MPPA: land division, pattern of public rights of way characterized by the road system and environmental conservation (including landscape and cultural assets). Comas and Bohrer (2011), as local urbanists, state that MPPA is complicated, spendthrift, anachronic and inflexible because it has low effectiveness in ordering the dynamics of occupation by populations.

Table 2 provides a comparison between the main provisions and effectiveness of the MPPA. They are described and discussed in the next two subsections.

\section{MPPA provisions and effectiveness for urban sprawl/density}

Urban planning is very well underpinned in the MPPA. Urban morphology is represented in maps of the MPPA related to land classification into residential, commercial, industrial and rural areas. According to Moreira (2010) and Dias (2011), the fast process of urbanization which took place in Porto Alegre especially since 1970 brought severe shifts in the topographic profile of occupation. Urban sprawl/density balance and areas of population density and expansion are provided in the MPPA especially under the established polycentric model of urban growth. The MPPA introduced "created soil", a strategy to enable city densification encouraging building vertical growth in selected areas, in order to ease urban mobility. However, in practice, uncontrolled sprawling arises as one of the main MPPA failures. The slopes of the hills in the East areas of the city exhibit high densities of irregular building, as a result of a lack of governmental planning.

Dias (2011) reviewed several studies that highlight the complexity of population growth, land occupation patterns and the semicircular shape that arose as a result of population sprawl in Porto Alegre. Soil impermeability has risen in popular residential areas, and at the same time horizontal residential condominiums owned by high income people have proliferated. The population

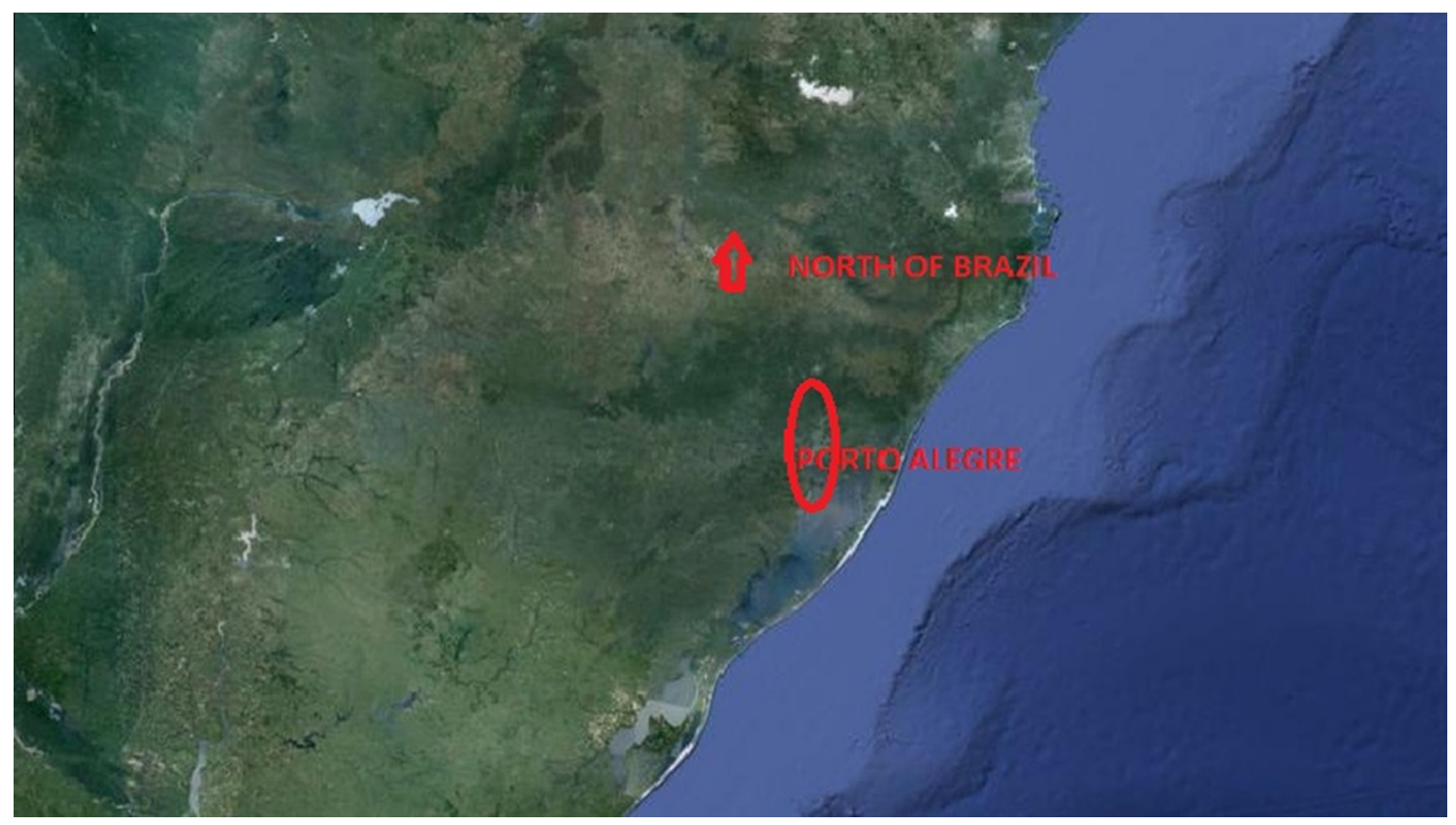

Fig. 1. Porto Alegre placement. Source: Google Earth. 
has grown around the fluvial plain lagoon and in the hills, with an average increase of $80 \%$ in the last decade. At the same time urban patches in the municipality grew from $40 \%$ to $45 \%$ of the whole area covered by the MPPA. Porto Alegre had a demographic boom from 1900 to 1960 , when the population grew from 73,000 to 635,000 residents, but between 1990 and 2000 the population growth stabilized at $9 \%$ (Troleis, 2009).

Real estate is a powerful pressure for urbanization because it stratifies the standards of residential units and often contributes to inequalities in housing that lead to an imbalance between low and high income people. The number of units offered in the city has increased 40\% from 1990 to 2010 (SINDUSCON-RS, 2011).

Pacheco (2007) identified a recent trend in housing behaviors of Porto Alegre citizens: people with higher income levels are moving from the old town (already urbanized) to horizontal buildings placed at peripheral areas, mainly in neighboring municipalities or in the South neighborhoods of the city. This phenomenon can be confirmed through satellite image analysis taken from 1986 (Fig. 2), 1997 (Fig. 3) and 2011 (Fig. 4). Georeferencing and processing of such Landsat images allows a conclusion that the urbanized area grew from $143,424 \mathrm{~km}^{2}$ in 1986 to $159,502 \mathrm{~km}^{2}(11.21 \%)$ in 1997, and to $174,682 \mathrm{~km}^{2}$ in 2011 (9.51\%). Although the percentage increase was lower for the most recent period (1997-2011), the visual information observable in the sequence of images enables one to conclude that significant sprawl took place in the South neighborhoods of the city, to the point of formation of a separate conurbation (whose evolution is highlighted with red $^{1}$ circles in Figs. 2-4).

\section{MPPA provisions and effectiveness for the control of building}

Building, regarding limits for density, construction patterns and heights, are well provided by the MPPA. It enforces drainage planning, preservation of green belts around watercourses, limits for occupation of buildings and proportionality regarding size and width of streets. Nevertheless, the effectiveness of controls on building distribution is criticized by Pacheco (2007). According to him, the MPPA fails to stimulate centralization and it is unable to control horizontal sprawl in the south areas of the city. Green building, a recommended provision for sustainable cities (Millard-Ball, 2012), is not included in the MPPA.

\section{MPPA provisions and effectiveness for transport/traffic/mobility}

The main provisions of the MPPA on transport, traffic and mobility is contained in the Urban Mobility Strategy, a set of initiatives for improving traffic safety and flow, reducing travel distances, and assuring the existence of safe places for pedestrian and cyclist mobility. However, there are few studies assessing traffic and mobility conditions. Benetti (2012) advises the participation of drivers and the improvement of signaling in order to increase the understanding about, and the speed of, traffic flow in the city.

Porto Alegre, in common with any Brazilian metropolis, experiences increasing traffic bottlenecks. The city has over 680,000 vehicles registered in Porto Alegre alone, not including the large fleet from outside that constantly flows in and out the city (DETRAN, 2011). Historically, the vehicle fleet of the city has shown an annual increase of 3-4\%, but since 2007 this has been increasing, as can be seen in Fig. 5. There is now one car for every 2.7 residents. The city has $2761 \mathrm{~km}$ of roads and, until the end of 2010, only $3.2 \mathrm{~km}$ of bicycle paths, although the latter are not continuous. In

\footnotetext{
${ }^{1}$ For interpretation of color in Figs. 2-4, the reader is referred to the web version of this article.
}

2011, the municipal administration delivered another $4.6 \mathrm{~km}$ of bicycle paths, and the total bike path is estimated to reach $17.4 \mathrm{~km}$ by 2013 (Ribeiro, Ribeiro, Guimarães, Morbin, \& Pires, 2011).

Considering the costs of public transportation to people, deaths in traffic per 100 residents, bicycle pathways extension, and the ratio between individual car journeys and public (bus) travel, Porto Alegre is just ahead of Cuiaba and Sao Paulo on the national capital ranking of urban mobility. One of the main problems is the high rates of casualties in urban traffic - 10 deaths per 100,000 residents (Ribeiro et al., 2011). Data about the number of kilometers travelled by person are not available.

\section{MPPA provisions and effectiveness for green spaces}

Green spaces are widely embraced by the MPPA. An amendment to the MPPA in 2010 determined the green areas ratio per capita, but there is no clear sign on how to monitor this indicator. The city has $14.78 \mathrm{~m}^{2}$ of green area per capita, above the minimum of $12 \mathrm{~m}^{2}$ recommended by the World Health Organization (SMAM, 2011).

Nevertheless, as a consequence of disorderly growth, the natural landscape of Porto Alegre has undergone severe losses, and the city retains just $24 \%$ of its natural vegetation cover (Hasenack, 2008). According to Hasenack (2008), farming areas, mainly in the South, are mixed with illegal building.

\section{MPPA provisions and effectiveness for energy}

There is just one provision for energy in the MPPA: the Energy Conservation Plan. However, no details are given on the objectives and targets of this plan. Specific data about energy saving are not available, although there is one study trying to assess the energy efficiency of the street lighting system (Teixeira (2012).

\section{MPPA provisions and effectiveness for biophysical aspects}

Biophysical aspects comprise a wide range of measures of the MPPA, through the Air Pollution Prevention Program, air quality assessment initiatives, public drainage to avoid floods, special areas for water resources protection, technical measures for assuring groundwater systems, protection policies for areas of natural interest, and public deliberation about created soil as an urban development tool. The rainfall, groundwater, ecology, sewerage and drainage systems of the city are well described by Hasenack (2008). He highlights aspects such as lack of data for preventing dramatic flood episodes and problems related to ground water quality. Regarding air quality, a recent study of Mario (2012) concludes that the MPPA does not consider air pollutant dispersion.

\section{MPPA provisions and effectiveness for climate}

MPPA has no provision for climatic stress, climate zones, temperature measurement in different areas of the city, and regional climate factors. There is a brief reference to climate as part of the urban ecosystem in article 88 of the MPPA, although climate policies are registered at Federal (Castello, 2011) and State (SEMA-RS Secretaria Estadual do Meio Ambiente do Rio Grande do Sul, 2011) levels. An analysis of the climate of Rio Grande do Sul between 1931 and 1990 shows that the average of the minimum temperatures has shown an increase of $0.4{ }^{\circ} \mathrm{C}$ (Rossatto, 2011). However, such data do not exist at municipal level. Hasenack (1989) was the only researcher to consider the effects of solar obstructions by building and vegetation, separately, in Porto Alegre. He collected data from April 1985 to March 1986 from six meteorological stations placed at points of the city with different landscape fea- 
Table 2

MPPA provisions for LUP.

\begin{tabular}{|c|c|}
\hline Article & Main text provisions \\
\hline 5 & Land use, transport and sanitation must be integrated. Proposes a system of articulated spaces for collective use \\
\hline 6 & Transit planning must reduce distances, improve logistics and give priority to cyclists and pedestrians \\
\hline 7 & $\begin{array}{l}\text { Classifies urban mobility in four categories: preference to pedestrian and cyclists, preference to general urban transport, preference to passengers and } \\
\text { loads, collective transport }\end{array}$ \\
\hline 8 & Traffic engineering must facilitate traffic flow. Determines traffic safety system \\
\hline 9 & Considers the integration between land use and vehicular traffic for street function \\
\hline 10 & Classifies urban streets according land use/occupation \\
\hline 11 & Defines a private strategy for soil use/land use \\
\hline 12 & Refers to land use as a technical, legal and administrative process to enable public participation \\
\hline 15 & Defines original ecosystems as part of the natural heritage of the city \\
\hline 17 & Defines open spaces as environmental qualified spaces \\
\hline 18 & $\begin{array}{l}\text { Establishes the Program of Implementation and Maintenance of Green Urban Areas - parks and squares. Proposes the Energetic Conservation Plan in order } \\
\text { to save energy. Proposes the Program of Pollution Prevention and Control as part of the Environmental Qualification Strategy }\end{array}$ \\
\hline 21 & Determines public safety management jointly with State authority \\
\hline 22 & Defines social welfare as liveability. Defines liveability as the quality of life patterns attainment in dwelling, transport, traffic, urban cleaning and safety \\
\hline 23 & Defines social welfare as liveability \\
\hline 26 & Recommends decentralization and land occupation according to city density and to polycentric model in order to control densification \\
\hline 27 & Defines types of areas according their population density and expansion patterns \\
\hline 28 & Distinguishes intensive occupation areas and rarefied areas. \\
\hline 29 & $\begin{array}{l}\text { Determines land subdivision in nine macrozones, according to the density and type of occupation (residential, commercial, industrial, rural, urban } \\
\text { activities) }\end{array}$ \\
\hline 30 & States open space as a category of the city spatial model \\
\hline 31 & States the polycentricity as a type of spatial planning \\
\hline 32 & Classifies areas of environmental protection, biological reservation, natural squares, rural properties \\
\hline 50 & Land use is defined according densification rules \\
\hline 53 & Defines "created soil" in order to allow intensive occupation and levels of densification \\
\hline 56 & $\begin{array}{l}\text { Determines reconfiguration of the sidewalk extension according to traffic volume. Air quality, flora and fauna must be assessed in Special Projects of } \\
\text { Urban Impact. Determines sewer system assessment in project of special urban impact }\end{array}$ \\
\hline 57 & Recommends special urban studies for activities that can increase traffic \\
\hline 66 & $\begin{array}{l}\text { Provides the monitoring of areas according their densification. Density is defined as a ratio between the intensity of land occupation and urban soil } \\
\text { occupation }\end{array}$ \\
\hline 71 & Provides the implementation of urban cadastre in order to monitor the urban densification by local authority \\
\hline 72,137 & Refers to safety of public equipment \\
\hline 76 & Defines social welfare as liveability \\
\hline 77 & Determines green areas ratio per capita according to parameters of the Municipal Organic Law \\
\hline 85 & Defines heights of building for coastal areas (neighborhoods) \\
\hline 86 & Defines areas of natural interest \\
\hline 88 & Provides special protection to ecological corridors with hydrological resources. Refers to climate as part of ecosystem \\
\hline 96 & $\begin{array}{l}\text { Orders limits for land use in building (air space, underground space). In building projects, public drainage must be planned. Green belts must be preserved } \\
\text { around watercourses/streams. Provides special protection for areas with hydrological resources }\end{array}$ \\
\hline 98 & Determines parameters for land densification \\
\hline 100 & Classifies zones according to land use and their environmental impact \\
\hline 103 & Determines balance between the number of garages and traffic volume in the same area \\
\hline 104105 & Provide patterns for building proportion regarding the size of the ground \\
\hline \multicolumn{2}{|r|}{ W } \\
\hline 106 & Refers to areas under densification according to current population density \\
\hline 107 & Supermarkets, according the density building, must reserve space for bicycle parks \\
\hline 110 & Refers to created soil and building potential in areas of intensive occupation \\
\hline 112 & Defines limits of occupation, heights and retreats for edification \\
\hline 113 & Define patterns of heights for building \\
\hline 114 & Determines height limits for buildings according to the width of the street \\
\hline 124 & Determines that buildings with garage must provide space for bicycle parking \\
\hline 135 & Determines the need of technical measures for groundwater systems \\
\hline 136 & Permanent Preservation Areas are protected areas, even within buildings. Provides measures to avoid floods \\
\hline 141 & Proposes restoration of the rural zone of the city \\
\hline 154 & Determines that public spaces must be mapped \\
\hline 164 & Determines that open spaces will be defined by the Municipal Council for Urban Development \\
\hline Page & Cartographical provisions \\
\hline 19 & Map of land classification - open spaces and urban geometry with main corridors. \\
\hline 2931 & $\begin{array}{l}\text { Map of environmental strategy - indicates the localization of squares, green areas, other landscape resources as well as recovered soil, recovered water } \\
\text { streams, recovered urban spaces. }\end{array}$ \\
\hline 39 & Map of land use and habitation density \\
\hline 41 & Region planning map \\
\hline 45 & Land planning - macrozones map \\
\hline 124 & Map of building height \\
\hline
\end{tabular}

Source: adapted from MPPA (2011) http://lproweb.procempa.com.br/pmpa/prefpoa/spm/usu_doc/planodiretortexto.pdf.

tures. He found a positive correlation between building density and rising temperature, and concluded that building density strongly influenced temperature variation. However, this research has had no follow up in more recent years.
For the purposes of the present research, the average monthly temperatures from 1931-1960, 1961-1990 (30 years for each range), 1991-2000 and 2001-2010 (10 years for each range) were analyzed using ANOVA with a 0.05 significance level. The results 


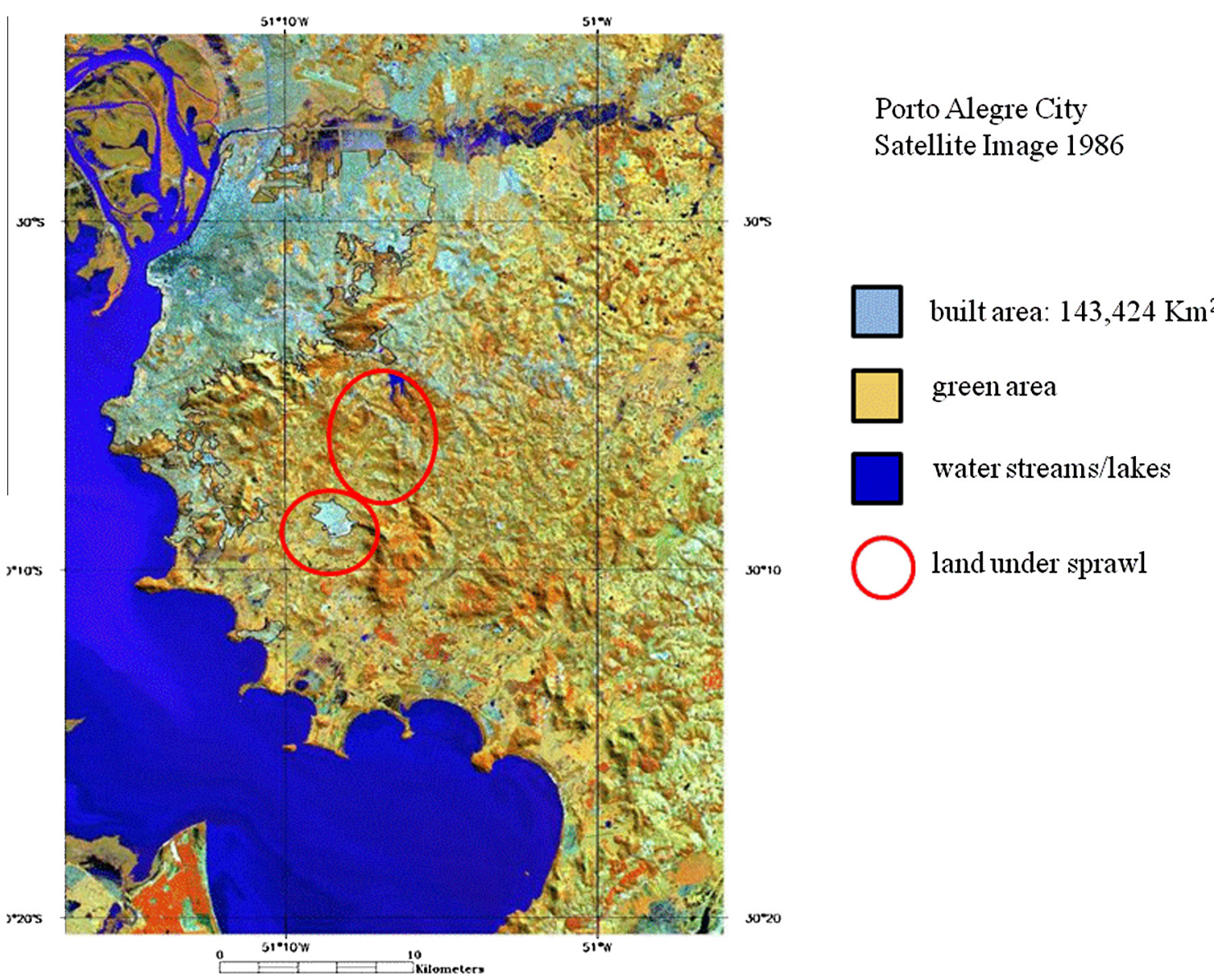

Fig. 2. Satellite image of Porto Alegre - 1986. Source: Landsat.

show that average temperatures observed in 1931-1960, 19611990 and 1991-2000 present no statistical difference. Nevertheless, average temperatures observed in 2001-2010 were significantly higher than those observed in the previous periods. The differences registered for the last decade were $+0.367{ }^{\circ} \mathrm{C}$ compared with 1931-1960, $+0.417^{\circ} \mathrm{C}$ compared with $1961-1990$ and $+0.392{ }^{\circ} \mathrm{C}$ compared with $1991-2000$. It can be concluded that the last 10 years has been hotter than the 70 years between 1931 and 2000. Fig. 6 shows the variations of average monthly temperatures for the considered ranges. Values corresponding to the most recent decade are separated from the remaining data.

\section{MPPA provisions and effectiveness for GHG emissions}

There are neither provisions nor assessments related to GHG emissions for Porto Alegre. At State level, the Air, Climate and Energy Plan of Rio Grande do Sul (SEMA-RS, 2011) has estimates for GHG emissions from several sources.

\section{MPPA provisions and effectiveness for cartographical data}

Cartographical representation of land is given by the MPPA through land classification maps and zoning maps. Geographic data are also embedded in land use maps, but there are neither climate maps nor satellite data in the MPPA. Hasenack (2008) provides detailed maps for land use, and satellite images obtained from the Landsat database, for the purposes of the present research (Figs. 2-4), show relevant information about urban sprawl, which are not available in the MPPA cartography.
MPPA provisions and effectiveness for social aspects

Among social aspects, safety and welfare are highlighted in the MPPA as safe traffic, safe mobility, and safe public equipment. Welfare is defined as liveability, or quality of life patterns, but this expression is not deployed in the MPPA. Social behavior towards the environment has no provision in the MPPA. Bedante (2004) found a positive correlation between ecological awareness and intention to purchase among Porto Alegre consumers in the last decade.

\section{Hotter and poorly planned: the failure of the MPPA plan to mitigate local climate change}

Models for assessing climate change at urban level are difficult to consolidate because of the pecularities of each urban settlement, in terms of natural and anthropogenic characteristics and development (Aydin \& Çukur, 2012). There is lack of consistent research to definitively state climate change as an urban phenomenon (Blakely, 2007; Fernau et al., 1993). This difficulty stems from the lack of research on climate change at small scales (Blanco et al., 2009; Dewan \& Yamaguchi, 2009; Khare, Beckman, \& Crouse, 2011). However, as urbanization increases around the world (Seto, Fragkias, Güneralp, \& Reilly, 2011), studies are being developed regarding local climate modeling (Grosling et al., 2012; Houet \& Pigeon, 2011; Sears et al., 2011). In addition, several studies on UHI and associating LUP with temperature variations in cities around the world show that urban environments are becoming warmer in recent decades (as seen in previous discussion about downscaling climate change to urban environments). 


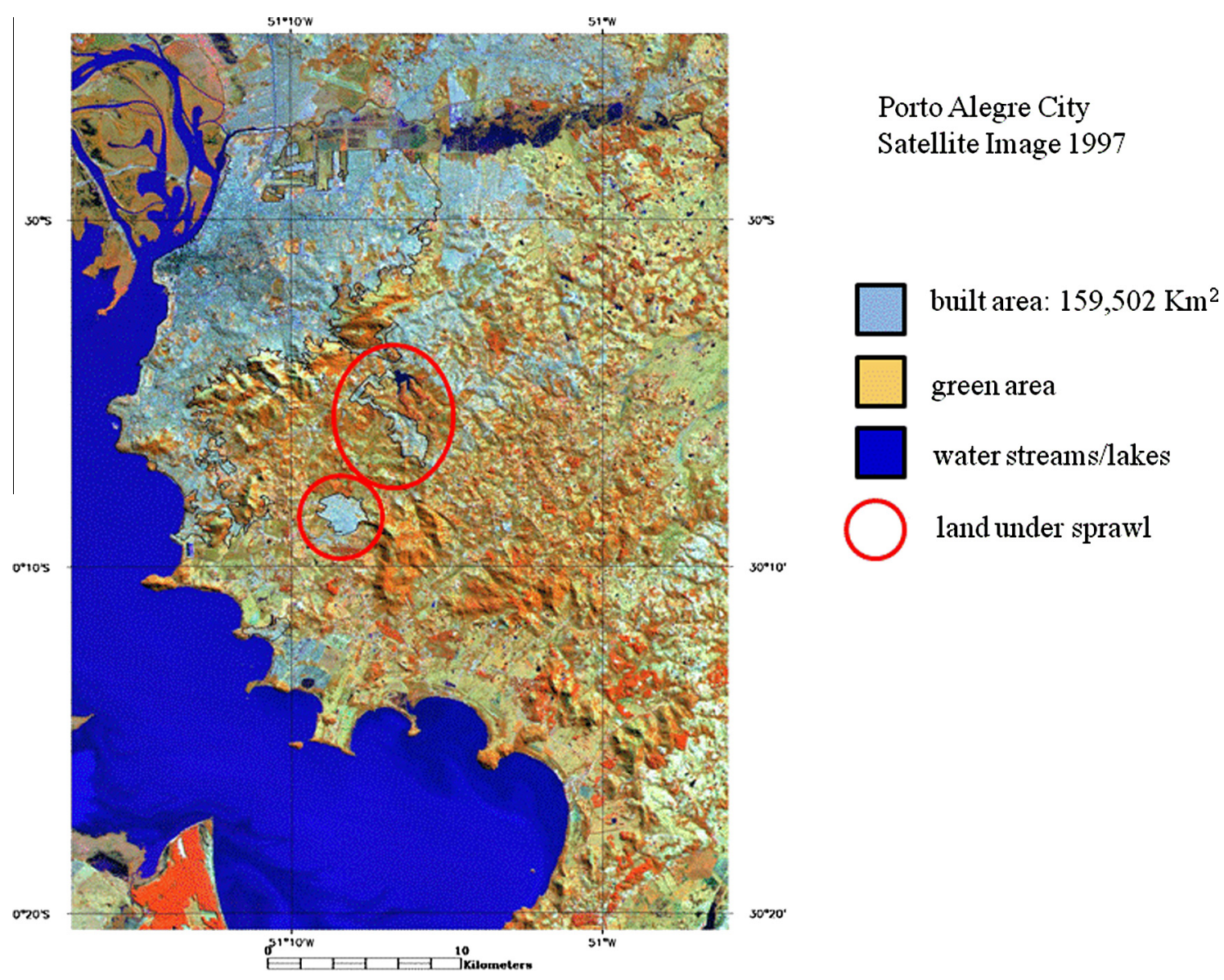

Fig. 3. Satellite image of Porto Alegre - 1997. Source: Landsat.

The development of a framework on LUP for the assessment of the effectiveness of the MPPA has confirmed the described difficulties for delineating local climate change in the case of Porto Alegre city. However, it is very difficult to identify the interactions between the various aspects to fully understand the complexity of the urban climatic environment and its evolution. There is need for a better understanding of the inter-relationship among technical and social variables, especially in order to understand the complex aspects linked to behavioral attitudes towards environment (Schwanen, Banister, \& Anable, 2011).

Through the assessment of each set of categories for LUP regarding climatic aspects, it was possible to conclude that the MPPA has no provisions for climate variation and GHG emissions, and incomplete provisions for building, transport/traffic/mobility, cartographical and social aspects. Air temperature measurements for Porto Alegre are taken in a single official meteorological station, and there are no other devices or scientifically established means for obtaining these data from other areas of the city; this surely fails to reflect the diverse building arrangements, population density, topography, relief and vegetation peculiarities that influence warming conditions at different locations within the city.

Regarding the effectiveness of the MPPA, obtained through the comparison of the MPPA provisions and available data on the city for each category of the framework, it is possible to conclude that the MPPA is not fully effective for building, transport/traffic/mobility, climate and cartographical data, and it is completely ineffective for energy use and GHG emissions.

The main criticism regarding the MPPA refers to uncontrolled urban sprawl in the Southern areas of the city - which can be observed through satellite images of 1986, 1997 and 2011. They con- firm the criticism raised by Comas (2011) about the low effectiveness of the MPPA towards the dynamics of population occupation. Similar criticism was already stated by Dias (2011), regarding the uncontrolled population expansion in the Southern areas, and the observation of Pacheco (2007) over the real state pressures towards the Southern neighborhoods caused by high income dwellers with their horizontal building initiatives.

Although the population growth of the city has maintained its level of growth in the last decade whilst the rate of increase of the total urbanized area has diminished from 1997 to 2011, compared with the period 1986 to 1997 , it is possible to state that the MPPA has not succeeded in overcoming basic gaps like irregular sprawl, lack of integration between land use and transportation, mobility improvement through the increase of bicycle paths, and establishment of public initiatives aimed at behavior change in terms of urban mobility and better harnessing of public spaces.

It is possible to conclude that the $0.367^{\circ} \mathrm{C}$ temperature increase registered in the last decade compared with the previous 10 years represents a warning for public planners to rethink several provisions of the MPPA, especially those related to climatic aspects and GHG emissions inventory, which is not held by the Master Plan. However, it is recommended that the proposed LUP framework should be further improved and tested in order to get a better integration of criteria and to better contribute to filling the MPPA gaps regarding the local climate shifts that has been registered.

Finally, it can be highlighted that:

- Climate change can be demonstrated at the urban level, associated with failures of LUP, but the lack of scientific models to represent it imposes obstacles for recognizing such phenomena. 


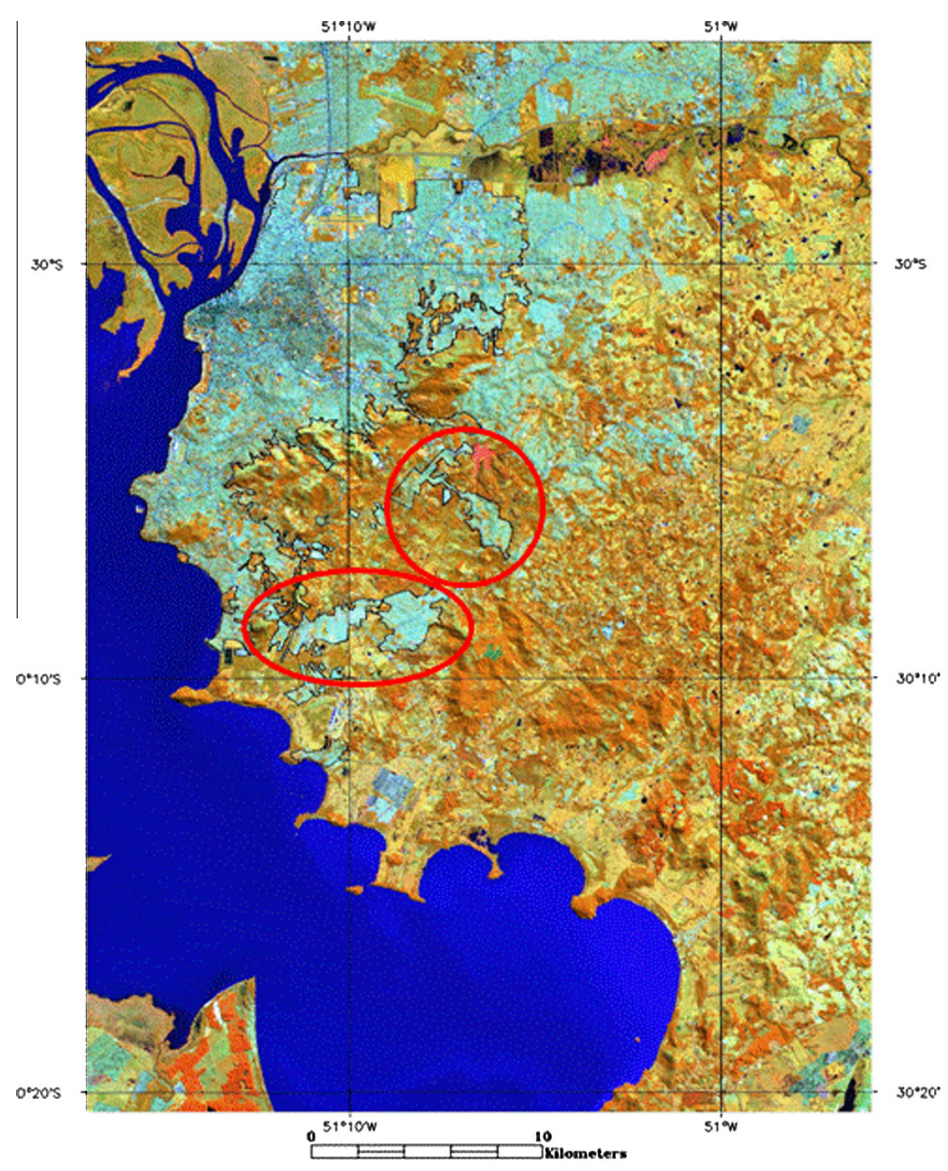

\author{
Porto Alegre City \\ Satellite Image 2011
}

\section{* Some water bodies presentedhigh algae concentration, which reflect the red color in this satellite image}

Fig. 4. Satellite image of Porto Alegre - 2011. Source: Landsat.

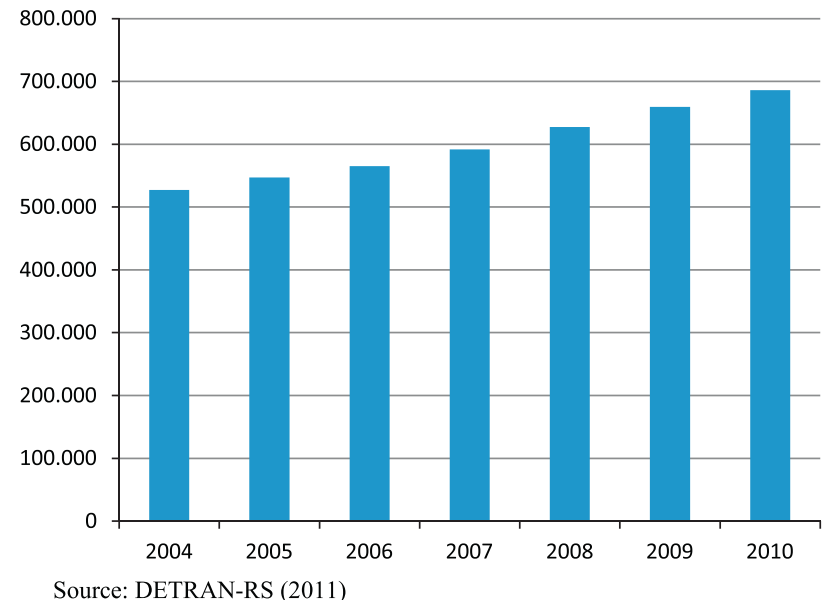

Fig. 5. Number of vehicles fleet by year in Porto Alegre. Source: DETRAN-RS (2011).

- The developed LUP framework is potentially valuable for wider application to studies examining local climate change in urban areas anywhere in the world, subsequent to further testing.

- Horizontal spatial sprawl related to land use in the Southern area of Porto Alegre was identified, and can be linked to rising temperatures, in agreement with conclusions drawn in several related urban studies (as already discussed).

- Evidence was found of significant temperature increase for Porto Alegre in the last decade compared with the previous decade, a result consistent with several aligned researches carried

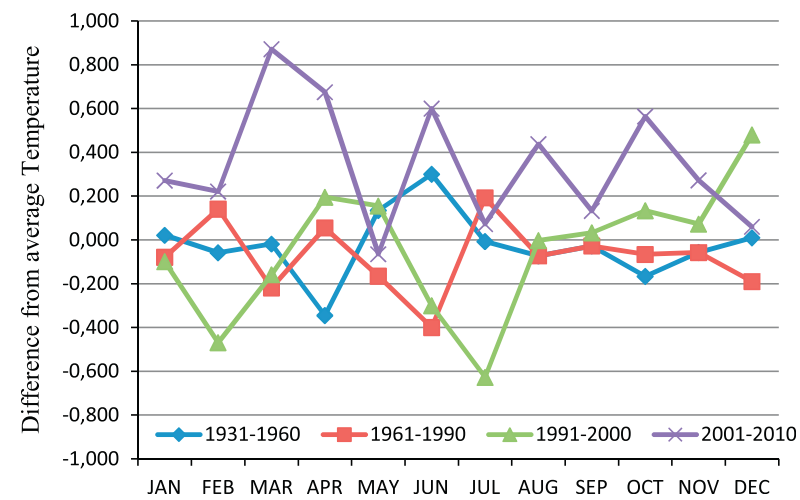

Fig. 6. Monthly average temperatures of Porto Alegre considering four periods.

out around the world (Section 'Downscaling climate change to urban environments').

- There is no municipal public provision for tackling climate change in the MPPA, although it is demonstrated to be relevant due to the increasing temperatures identified in recent decades.

\section{Acknowledgments}

We acknowledge CAPES and CNPq (Brazilian research institutes) for the grants provided for funding this research; Geosciences Institute of the Federal University of Rio Grande do Sul; and National Institute of Meteorology (8th District of Meteorology) for the technical support. 


\section{Appendix A. Supplementary material}

Supplementary data associated with this article can be found, in the online version, at http://dx.doi.org/10.1016/j.cities.2013.05. 006. These data include Google maps of the most important areas described in this article.

\section{References}

Adger, W. N., Arnell, N. W., \& Tompkins, E. L. (2005). Successful adaption to climate change across scales. Global Environmental Change, 15, 77-86.

Alcoforado, M. J., Andrade, H., Lopes, A., \& Vasconcelos, J. (2009). Application of climatic guidelines to urban planning: The example of Lisbon (Portugal). Landscape and Urban Planning, 90, 56-65.

Aydin, M. B. S., \& Çukur, D. (2012). Maintaining the carbon-oxygen balance in residential areas: A method proposal for land use planning. Urban Forestry $\mathcal{E}$ Urban Greening, 11, 87-94.

Batty, M. (2012). Building a science of cities. Cities, 29, S9-S16.

Bedante, G. N. (2004). A influência da consciência ambiental e das atitudes em relação ao consumo sustentável na intenção de compra de produtos ecologicamente embalados (The influence of environmental awareness and attitudes towards sustainable consumption on intention to purchase ecologically packaged products). Master thesis. Management Post Graduation Program. Federal University of Rio Grande do Sul, Porto Alegre, 159p.

Benetti, L. S. (2012). Método de avaliação das condições de fluidez do tráfego para provisão de informações através de painéis de mensagem variável (Evaluation method of traffic flow conditions for the provision of information through variable message signs). Master thesis. Industrial Engineering Post Graduation Program. Federal University of Rio Grande do Sul, Porto Alegre, 69p.

Bentley, M. (2007). Healthy Cities, local environmental action and climate change. Health Promotion International, 22(3), 246-253.

Benzerzour, M., Masson, V., Groleau, D., \& Lemonsu, A. (2011). Simulation of the urban climate variations in connection with the transformations of the city of Nantes since the 17th century. Building and Environment, 46, 1545-1557.

Blakely, E. J. (2007). Urban planning for climate change. Lincoln Institute of Land Policy. Working paper WP07EB1, 29p. <http://www.lincolninst.edu/pubs/ download.asp?doc_id=604\&pub_id=1310>. Accessed 25.05.12.

Blanco, H., Alberti, M., Forsyth, A., Krizek, K. J., Rodríguez, D. A., Talen, E., \& Ellis, C. (2009). Hot, congested, crowded and diverse: Emerging research agendas in planning. Progress in Planning, 71, 153-205.

Cabanillas, F. J. J., Aliseda, J. M., Gallego, J. A. G., \& Jeong, J. S. (2013). Comparison of regional planning strategies: Countywide general plans in USA and territorial plans in Spain. Land Use Policy, 30, 758-773.

Cantarello, E., Newton, A. C., \& Hill, R. A. (2011). Potential effects of future land-use change on regional carbon stocks in the UK. Environmental Science and Policy, 14, 40-52.

Castello, M. G. (2011). Brazilian policies on climate change: The missing link to cities. Cities, 28, 498-504.

Comas, C. E., \& Bohrer, G. (2011). Dispositivos de controle, planos diretores e uma celeuma sem base. In A Necessária Releitura da Cidade. Secretaria Municipal de Planejamento Urbano (Control devices, master plans and a stir baseless. The Necessary Re-reading of the City). <http://www.portoalegre.rs.gov.br/planeja/ $\mathrm{spm} 2 / 25 . \mathrm{htm}>$. Accessed 17.10.11.

Cooney, C. M. (2012). Downscaling climate models: Sharpening the focus on local Level changes. Environmental Health Perspectives, 120(1), A22.

De Nazelle, A., Nieuwenhuijsen, M. J., Antó, J. M., Brauer, M., Briggs, D., BraunFahrlander, C., Cavill, N., Cooper, A. R., Desqueyrouxi, H., Fruin, S., Hoek, G., Panis, L. I., Janssen, N., Jerrett, M., Joffe, M., Andersen, Z. J., van Kempen, E. Kingham, S., Kubesch, N., Leyden, K. M., Marshall, J. D., Matamala, J., Mellios, G. Mendez, M., Nassif, H., Ogilvie, D., Peiró, R., Pérez, K., Rabl, A., Ragettli, M. Rodríguez, D., Rojas, D., Ruiz, P., Sallis, J. F., Terwoert, J., Toussaint, J. F., Tuomisto, J., Zuurbier, M., \& Lebret, E. (2011). Improving health through policies that promote active travel: A review of evidence to support integrated health impact assessment. Environment International, 37, 766-777.

DETRAN-RS (2011). (Traffic State Authority of Rio Grande do Sul, Brazil). Statistics. $<$ http://www.detran.rs.gov.br/index.php?action=estatistica\&cod=10>. Accessed 16.09.11.

Dewan, A. M., \& Yamaguchi, Y. (2009). Land use and land cover change in Greater Dhaka, Bangladesh: Using remote sensing to promote sustainable urbanization. Applied Geography, 29, 390-401.

Dias, T. S. (2011). A Expansão da Ocupação Urbana sobre o Relevo do Município de Porto Alegre (The Expansion of Urban Occupation on the Relief of Porto Alegre). Monography. Institute of Geosciences. Federal University of Rio Grande do Sul, Porto Alegre Brazil, 91p.

Dodman, D. (2009). Urban density and climate change. Report. United Nations Population Fund (UNFPA) Analytical Review of the Interaction between Urban Growth Trends and Environmental Changes. April 2nd, 23p.

Elagib, N. A., \& Abdu, A. S. A. (2010). Development of temperatures in the Kingdom of Bahrain from 1947 to 2005. Theoretical and Applied Climatology, 101, 269-279.

Eliasson, I., \& Svensson, M. K. (2003). Spatial air temperature variations and urban land use - A statistical approach. Meteorological Applications, 10, 135-149.
Emmanuel, R., \& Krüger, E. (2012). Urban heat island and its impact on climate change resilience in a shrinking city: The case of Glasgow, UK. Building and Environment, 53, 137-149.

FEE-RS (2011). Fundação de Economia e Estatística do Rio Grande do Sul (Economic and Statistics Foundation of Rio Grande do Sul) Sumário Estatístico dos Municípios (Statistic Summary of Municipalities), Porto Alegre. <http://www.fee.tche.br/ sitefee/pt/content/resumo/ pg_municipios_detalhe.php?municipio=Porto+Alegre>. Accessed 14.10. 11.

Fernau, M. E., Makofske, W. J., \& South, D. W. (1993). Review and impacts of climate change uncertainties. Futures, 25(8), 850-863.

Fischer, T., Gemmer, M., Lüliu, L., \& Buda, S. (2011). Temperature and precipitation trends and dryness/wetness pattern in the Zhujiang River Basin, South China, 1961-2007. Quaternary International, 244, 138-148.

Frumkin, H., Hess, J. J., \& Stone, B. (2010). Urban form and extreme heat events: Are sprawling cities more vulnerable to climate change than compact cities? Environmental Health Perspectives, 118, 1425-1428.

Grimm, N. B., Faeth, S. H., Golubiewski, N. E., Redman, C. L., Wu, J., Bai, X., \& Briggs, J. M. (2008). Global change and the ecology of cities. Science, 319, 756-760 (February 8th).

Grosling, S. N., McGregor, G. R., \& Lowe, J. A. (2012). The benefits of quantifying climate model uncertainty in climate change impacts assessment: An example with heat-related mortality change estimates. Climatic Change, 112, 217-231.

Gu, C., Hua, L., Zhang, X., Wang, X., \& Guo, J. (2011). Climate change and urbanization in the Yangtze River Delta. Habitat International, 35, 544-552.

Hallegatte, S., \& Henriet, F. (2011). The economics of climate change impacts and policy benefits at city scale: A conceptual framework. Climatic Change, 104, 51-87.

Hamin, E. H., \& Gurran, N. (2009). Urban form and climate change: Balancing adaptation and mitigation in the US and Australia. Habitat International, 33, 238-245.

Harlan, S. L., \& Ruddell, D. M. (2011). Climate change and health in cities: Impacts of heat and air pollution and potential co-benefits from mitigation and adaptation. Current Opinion in Environmental Sustainability, 3, 126-134.

Hasenack, H. (1989). Influência de variáveis ambientais sobre a temperatura do ar na área urbana de Porto Alegre (Influence of environmental variables on the air temperature in urban area of Porto Alegre) Master thesis. Geosciences Institute, Federal University of Rio Grande do Sul, Porto Alegre, Brazil.

Hasenack, H. (2008). Diagnóstico ambiental de Porto Alegre: Geologia, Solos, Drenagem, Vegetação/Ocupação e Paisagem (Environmental diagnostic of Porto Alegre: Geology, soils, drainage, vegetation/occupation and landscape). Secretaria Municipal do Meio Ambiente (Environment Municipal Secretary), Porto Alegre, Brazil.

He, J., Bao, C. K., Shu, T. F., Yun, X. X., Jiang, D., \& Brown, L. (2011). Framework for integration of urban planning, strategic environmental assessment and ecological planning for urban sustainability within the context of China. Environmental Impact Assessment Review, 31, 549-560.

Heinonen, J., Kyrö, R., \& Junila, S. (2011). Dense downtown living more carbon intense due to higher consumption: A case study of Helsinki. Environmental Research Letter, 6, 034034 (9pp).

Hidalgo, J., Masson, V., Baklanov, A., Pigeon, G., \& Gimeno, L. (2008). Advances in urban climate modeling. Trends and Directions in Climate Research: Annals of the New York Academy of Sciences, 1146, 354-374.

Houet, T., \& Pigeon, G. (2011). Mapping urban climate zones and quantifying climate behaviors. An application on Toulouse urban area (France). Environmental Pollution, 159, 2180-2192.

House-Peters, L. A., \& Chang, H. (2011). Modeling the impact of land use and climate change on neighborhood-scale evaporation and nighttime cooling: A surface energy balance approach. Landscape and Urban Planning, 103, 139-155.

Hu, Y., \& Jia, G. (2010). Influence of land use change on urban heat island derived from multi-sensor data. International Journal of Climatology, 30, 1382-1395.

Huang, G., Zhou, W., \& Cadenasso, M. L. (2011). Is everyone hot in the city? Spatial pattern of land surface temperatures, land cover and neighborhood socioeconomic characteristics in Baltimore, MD. Journal of Environmental Management, 92, 1753-1759.

Hulme, M., Dessai, S., Lorenzoni, I., \& Nelson, D. R. (2009). Unstable climates: Exploring the statistical and social constructions of 'normal' climate. Geoforum, 40, 197-206.

Hunt, A., \& Watkiss, P. (2011). Climate change impacts and adaptation in cities: A review of the literature. Climatic Change, 104, 13-49.

Jabareen, J. (2012). Planning the resilient city: Concepts and strategies for coping with climate change and environmental risk. Cities. http://dx.doi.org/10.1016/ j.cities.2012.05.004 (in press)

Jankovic, V., \& Hebbert, M. (2012). Hidden climate change - Urban meteorology and the scales of real weather. Climatic Change, 113, 23-33.

Jusuf, S. K., Wong, N. H., Hagen, E., Anggoro, R., \& Hong, Y. (2007). The influence of land use on the urban heat island in Singapore. Habitat International, 31, 232-242.

Kadioglu, Y. (2011). Land use and major issues of planning in city of Trabzon. Procedia Social and Behavioral Sciences, 19, 354-362.

Kamal-Chaoui, L., \& Robert, A. (Eds.) (2009). Competitive cities and climate change. OECD regional development working papers no. 2. OECD Publishing, 172p.

Karaca, M., Tayanç, M., \& Toros, H. (1995). Effects of urbanization on climate of Istanbul and Ankara. Atmospheric Environment, 29(23), 3411-3421.

Keenleyside, C., Baldock, D., Hjerp, P., \& Swales, W. (2009). International perspectives on future land use. Land Use Policy, 26S, S14-S29. 
Khare, A., Beckman, T., \& Crouse, N. (2011). Cities addressing climate change: Introducing a tripartite model for sustainable partnership. Sustainable Cities and Society, 1, 227-235.

Kim, M., \& Kim, S. (2011). Quantitative estimates of warming by urbanization in South Korea over the past 55 years (1954-2008). Atmospheric Environment, 45, 5778-5783.

La Greca, P., Barbarossa, L., Ignaccolo, M., Inturri, G., \& Martinico, F. (2011). The density dilemma. A proposal for introducing smart growth principles in a sprawling settlement within Catania Metropolitan Area. Cities, 28, $527-535$.

Lankao, P. R. (2008). Urban areas and climate change: review of current issues and trends - Issues paper for the 2011 global report on human settlements, 101p. <http://www.ral.ucar.edu/staff/prlankao/GRHS_2011_IssuesPaperfinal.pdf>. Accessed 15.09.11

Lautenbach, S., Kugel, C., Lausch, A., \& Seppelt, R. (2011). Analysis of historic changes in regional ecosystem service provisioning using land use data. Ecological Indicators, 11, 676-687.

Lehmann, S. (2012). Can rapid urbanisation ever lead to low carbon cities? The case of Shanghai in comparison to Potsdamer Platz Berlin. Sustainable Cities and Society, 3, 1-12.

Liberman, L. N., \& Saffer, G. S. (2011). Um longo e seletivo caminho. In: A Necessária Releitura da Cidade. (A long and selective path. In The necessary re-reading of the city). Secretaria Municipal de Planejamento Urbano de Porto Alegre (Urban Municipal Planning Office of Porto Alegre City Hall), Brazil. <http:// www.portoalegre.rs.gov.br/planeja/spm2/8.htm>. Accessed 14.09.11.

Marengo, J. A., Chou, S. C., Kay, G., Alves, L. M., Pesquero, J. F., Soares, W. R., et al. (2011). Development of regional future climate change scenarios in South America using the Eta CPTEC/HadCM3 climate change projections: Climatology and regional analyses for the Amazon, São Francisco and the Paraná River basins. Climate Dynamics. http://dx.doi.org/10.1007/s00382-011-1155-5. 20p.

Mario, J. P. M. (2012). Poluição atmosférica como condicionante no processo de ocupação do espaço urbano: análise na cidade de Porto Alegre, RS (Air pollution as a condition in the process of occupation of urban space: analysis in Porto Alegre, RS). Master thesis. Urban and Regional Planning Post Graduation Program. Federal University of Rio Grande do Sul, Porto Alegre, 87p.

Mascarenhas, A., Ramos, T. B., \& Nunes, L. (2012). Developing an integrated approach for the strategic monitoring of regional spatial plans. Land Use Policy, 29, 641-651.

McCarthy, M. P., Best, M. J., \& Betts, R. A. (2010). Climate change in cities due to global warming and urban effects. Geophysical Research Letters V, 37, L09705. http://dx.doi.org/10.1029/2010GL042845.

McDonald, R.I., Green, P., Balk, D., Fekete, B.M., Revenga, C., Todd, M., et al. (2001). Urban growth, climate change, and freshwater availability 2011:1-6. In Proceedings of the national academy of sciences of the United States of America (pp. 6312-6317). April 12nd, 108.15. <http://www.pnas.org/content/suppl/ 2011/03/22/1011615108.DCSupplemental>. Accessed 15.08.11.

Millard-Ball, A. (2012). Do city climate plans reduce emissions? Journal of Urban Economics, 71, 289-311.

Moreira, L. G. R. (2010). Análise da Supressão de Áreas Verdes na Zona Sul de Porto Alegre: O Caso dos Bairros Cristal e Espírito Santo (Analysis of the suppression of green areas in South Section of Porto Alegre: The cases of Cristal and Espirito Santo neighborhoods). Monography. Institute of Geosciences. Federal University of Rio Grande do Sul, Porto Alegre, Brazil, 105p.

Moser, C., Norton, A., Stein, A., Georgieva, S. (2010) Pro-ppor Adaptation to Climate Change in Urban Centers: Case Studies of Vulnerability and Resilience in Kenya and Nicaragua. Report N 54947-GLB. The World Bank Sustainable Development Network. <http://siteresources.worldbank.org/EXTSOCIALDEVELOPMENT/ Resources/244362-1232059926563/5747581-1239131985528/ ESW_propoorurbanadaptationReport4947GLBweb2.pdf $>$. Accessed 15.03.13.

Musacchio, L., Ozdenerol, E., Bryant, M., \& Evans, T. (2005). Changing landscapes, changing disciplines: Seeking to understand interdisciplinarity in landscape ecological change research. Landscape and Urban Planning, 73, 326-338.

Pacheco, M. P. S. (2007). Expansão e tendências do mercado imobiliário de Porto Alegre (2005-2007): um ensaio sobre a aplicação do regime urbanístico do Plano Diretor de Desenvolvimento Urbano e Ambiental em uma área da cidade (Expansion and trends of the real estate market of Porto Alegre - 2005-2007: An essay about the application of the urban scheme of the Urban and Environmental Master Plan in one city's area). Monography, 49p. Institute of Geosciences. Federal University of Rio Grande do Sul, Porto Alegre, Brazil.

Parker, D. E. (2010). Urban heat island effect on estimate of observed climate change. Wiley Interdisciplinary Reviews: Climate Change, 1.1(January-February), 123-133.

Patz, J., Campbell-Lendrum, D., Gibbs, H., \& Woodruff, R. (2008). Health impact assessment of global climate change: Expanding on comparative risk assessment approaches for policy making. Annual Review of Public Health, 29, 27-39.

Qian, Z. (2010). Without zoning: Urban development and land use controls in Houston. Cities, 27, 31-41.

Ribeiro, R., Ribeiro, C., Guimarães, T., Morbin, B., \& Pires, C. (2011). Estudo Mobilize 2011. Diagnóstico da Mobilidade Urbana Sustentável em Capitais Brasileiras (Mobilize Study 2011. Diagnostic of Sustainable Urban Mobility in Brazilian Capitals). Relatório (Report), São Paulo, 69p.

Rossatto, M. S. (2011). Os climas do Rio Grande do Sul: Variabilidades, tendências, tipologias. Doctorat dissertation. (The climates of Rio Grande do Sul: Variability, trends and typologies) Institute of Geosciences. Federal University of Rio Grande do Sul, Porto Alegre, Brazil.
Roy, M. (2009). Planning for sustainable urbanisation in fast growing cities: Mitigation and adaptation issues. Habitat International, 33, 276-286.

Sager, T. (2011). Neo-liberal urban planning policies: A literature survey 1990 2010. Progress in Planning, 76, 147-199.

Saizen, I., Mizuno, K., \& Kobayashi, S. (2006). Effects of land-use master plans in the metropolitan fringe of Japan. Landscape and Urban Planning, 78, 411-442.

Salvati, L., Munafo, M., Morelli, V. G., \& Sabbi, A. (2012). Low-density settlements and land use changes in a Mediterranean urban region. Landscape and Urban Planning, 105, 43-52.

Satterthwaite, D. (2007) Climate change and urbanization: Effects and implications for urban governance. Report. United Nations Expert Group Meeting on Population Distribution, Urbanization, Internal Migration and Development. Population Division. Department of Economic and Social Affairs United Nations Secretariat 29p. <http://www.un.org/esa/population/meetings/EGM_PopDist/ P16_Satterthwaite.pdf $>$. Accessed 14.09.11.

Schiermeier, Q. (2010). The real holes in climate science. Nature, 463(January) 284-287.

Schwanen, T., Banister, D., \& Anable, J. (2011). Scientific research about climate change mitigation in transport: A critical review. Transportation Research Part A, 45(2011), 993-1006.

Sears, M. W., Raskin, E., \& Angilletta, M. J. Jr., (2011). The world is not flat: Defining relevant thermal landscapes in the context of climate change. Integrative and Comparative Biology, 51(5), 666-675.

SEMA-RS - Secretaria Estadual do Meio Ambiente do Rio Grande do Sul (2011). PACE - Plano Ar, Clima e Energia do Rio Grande do Sul. Relatório final (PACE - Air climate and energy plan of Rio Grande do Sul. Final report), 262p. <http:// www.fepam.rs.gov.br/Documentos_e_PDFs/RELATORIO_PACE_FINAL.pdf>. Accessed 15.06.12.

Seto, K., Fragkias, M., Güneralp, B., \& Reilly, M. K. (2011). A meta-analysis of global urban land expansion. PLoS One, 6(8), e23777. http://dx.doi.org/10.1371/ journal.pone.0023777: 1-9.

Seto, K. C., Sánchez-Rodríguez, R. M., \& Fragkias, M. (2010). The new geography of contemporary urbanization and the environment. Annual Review of Environment and Resources, 35, 167-194.

Shen, L.-Y., Ochoa, J., Shah, M. N., \& Zhang, X. (2011). The application of urban sustainability indicators - A comparison between various practices. Habitat International, 35, 17-29.

Sheppard, S. R. J., Shaw, A., Flanders, D., Burch, S., Wiek, A., Carmichael, J., Robinson, J., \& Cohen, S. (2011). Future visioning of local climate change: A framework for community engagement and planning with scenarios and visualization. Futures, $43,400-412$.

Shoshany, M., \& Goldshleger, N. (2002). Land-use and population density changes in Israel-1950 to 1990: Analysis of regional and local trends. Land Use Policy, 19, $123-133$.

SINDUSCON-RS (2011). Sindicato da Indústria da Construção Civil do Estado do Rio Grande do Sul (Civil Union Building of Rio Grande do Sul, Brazil). XIV Censo do Mercado Imobiliário de Porto Alegre (XIV Census of Porto Alegre's Real Estate Market). <http://www.sinduscon-rs.com.br/site/imagesdin/89_censo2011.pdf>. Accessed 14.09.011.

SMAM (2011). Secretaria Municipal do Meio Ambiente de Porto Alegre (Municipal environmental office of Porto Alegre). Áreas Verdes (Green Areas). <http:// www2.portoalegre.rs.gov.br/smam/default.php?p_secao=283>. Accessed 15.09.12.

Solecki, W. D., Rosenzweig, C., Pope1, G., Chopping, M., Goldberg, R., \& Polissar, A (2004). Urban heat island and climate change: An assessment of interacting and possible adaptations in the Camden, New Jersey Region. Environmental Assessment and Risk Analysis Element. Research Project Summary. State of New Jersey, Department of Environmental Protection, Division of Science, Research and Technology, 5p. <http://www.state.nj.us/dep/dsr/research/ urbanheat.pdf $>$. Accessed 12.09.11.

Solecki, W., \& Oliveri, C. (2004). Downscaling climate change scenarios in an urban land use change model. Journal of Environmental Management, 72, 105-115.

Song, L., Cannon, A. J., \& Whitfield, P. H. (2007). Changes in seasonal patterns of temperature and precipitation in china during 1971-2000. Advances in Atmospheric Sciences, 24(3), 459-473.

SPM (2011). Secretaria de Planejamento Urbano de Porto Alegre (Urban Municipal Planning Office of Porto Alegre City Hall. Porto Alegre tem tradição em planejamento (Porto Alegre has planning tradition). <http://www2. portoalegre.rs.gov.br/spm/default.php?p_secao=125>. Accessed 14.10.11.

Stephenson, J., Newman, K., \& Mayhew, S. (2010). Population dynamics and climate change: What are the links? Journal of Public Health, 32(2), 150-156.

Stone, B., Vargo, J., \& Habeeb, D. (2012). Managing climate change in cities: Will climate action plans work? Landscape and Urban Planning, 107, 263-271.

Tayanç, M., \& Toros, H. (1997). Urbanization effects on regional climate change in the case of four large cities of Turkey. Climatic Change, 35, 501-524.

Teixeira, P.R.M. (2012) Eficiência Energética da Iluminação Pública de Porto Alegre, Projeto de Diplomação. Escola de Engenharia. Departamento de Engenharia Elétrica. Universidade Federal do Rio Grande do Sul. Trabalho de Graduação, 87p. [Energetic Efficiency of Porto Alegre Public Lighting. Engineering School. Electric Engineering Department. Federal University of Rio Grande do Sul Graduation work, 87p.] <http://www.lume.ufrgs.br/bitstream/handle/10183/ 65423/000858185.pdf? sequence $=1>$. Accessed 16.03 .

Tiwari, R., Cervero, R., \& Schipper, L. (2011). Driving $\mathrm{CO}_{2}$ reduction by integrating transport and urban design strategies. Cities, 28, 394-405.

Tokairin, T., Sofyanb, A., \& Kitada, T. (2010). Effect of land use changes on local meteorological conditions in Jakarta, Indonesia: Toward the evaluation of the 
thermal environment of megacities in Asia. International Journal of Climatology, 30, 1931-1941.

Troleis, A. L. (2009). Metrópole de risco: o caso da Vila Dique e do Aterro Sanitário do Zona Norte na poluição das águas superficiais e subterrâneas das bacias hidrográficas do Arroio da Areia e Passo das Pedras (Metropolis of risk: The case of Dique Village and North Zone in superficial and groundwater pollution of watersheds of Areia Stream and Passo das Pedras). Doctorat dissertation, 313p. Institute of Geosciences. Federal University of Rio Grande do Sul, Porto Alegre, Brazil.

Uherek, E., Halenk, T., Borken-Kleefeld, J., Balkanski, Y., Berntsen, T., Borrego, C., Gauss, M., Hoor, P., Juda-Rezler, K., Lelieveld, J., Melas, D., Rypdal, K., \& Schmid, S. (2010). Transport impacts on atmosphere and climate: Land transport. Atmospheric Environment, 44, 4772-4816.

van der Voet, H., van der Heidjen, G. W. A. M., Bos, P. M. J., Bosgra, S., Boon, P. E., Muri, S. D., et al. (2009). A model for probabilistic health impact assessment of exposure to food chemicals. Food and Chemical Toxicology, 47, 2926-2940.

Wegener, M. (2001). New spatial planning models. International Journal of Applied Earth Observation and Geoinformation, 3(3), 224-237.
Wende, W., Bond, A., Bobylev, N., \& Stratmann, L. (2012). Climate change mitigation and adaptation in strategic environmental assessment. Environmental Impact Assessment Review, 32, 88-93.

Willoughby, C. (2012). How much can public private partnership really do for urban transport in developing countries? Research in Transportation Economics, 1-22. http://dx.doi.org/10.1016/j.retrec.2012.06.038 (in press).

Wu, K., \& Zhang, H. (2012). Land use dynamics, built-up land expansion patterns, and driving forces analysis of the fast-growing Hangzhou metropolitan area, eastern China (1978-2008). Applied Geography, 34, 137-145.

Yang, F., Zeng, G., Du, C., Tang, L., Zhou, J., \& Li, Z. (2008). Spatial analyzing system for urban land-use management based on GIS and multi-criteria assessment modeling. Progress in Natural Science, 18, 1279-1284.

Yin, R.K. (2009). Case study research. Design and Methods, fourth edition, Sage Inc.

Yoon, S. W., \& Lee, D. K. (2003). The development of the evaluation model of climate changes and air pollution for sustainability of cities in Korea. Landscape and Urban Planning, 63, 145-160.

Zhao, C., Fu, G., Liu, X., \& Fu, F. (2011). Urban planning indicators, morphology and climate indicators: A case study for a north-south transect of Beijing, China. Building and Environment, 46, 1174-1183. 